\title{
The New French Preferred Shares: Moving towards a More Liberal Approach
}

by

\author{
Pierre-Henri Conac**
}

The recent French June 24, 2004 Ordinance significantly reforms the regulation on securities issued by certain commercial companies (Sociétés anonymes or joint-stock companies, Sociétés en commandite par actions or partnerships limited by shares, Sociétés par actions simplifiées or simplified joint-stock companies). It establishes a new general type of security called action de préférence or preferred share. This new type of security replaces the former different types of priority shares that could be established before with one single and more flexible regime. Besides, the Ordinance allows the suppression of voting rights in joint-stock companies, which French lawmakers had been reluctant to allow so far. By doing so, the French lawmakers offer more freedom and have reduced the importance of the equality among shareholders principle which was the usual keystone of French corporate law. Besides, once again, French corporate law get its inspiration from the United States. However, the French approach to preferred shares keeps some specificities, both good or bad, compared to its American model.

\section{Table of Contents $\quad$ ECFR 2005, 487-511}

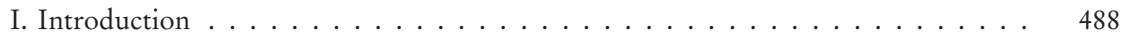

II. The nature of the preference . . . . . . . . . . . . . . . . . . . . . . 494

1. Ordinary preferred shares . . . . . . . . . . . . . . . . . . 494

2. Specific preferred shares . . . . . . . . . . . . . . . . . . . . 499

III. The regime of preferred shares . . . . . . . . . . . . . . . . . . . 502

1. Creation and suppression of preferred shares . . . . . . . . . . . . 502

2. Protection of holders of preferred shares . . . . . . . . . . . . 508

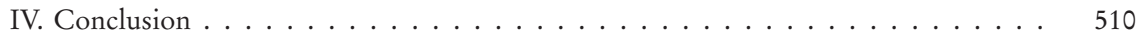

* Dr., Senior Lecturer in Private Law, University of Paris 1 (Panthéon-Sorbonne), LL.M. (Columbia Law School). 


\section{Introduction}

The creation of the preferred shares takes place in a period of legal activism and liberalization. Indeed, French corporate and securities laws have undergone an unprecedented series of major reforms since 2001 and the new regime of preferred shares stands among the top of them.

This legal activism is actually not specific to the area of corporate and securities law but was specifically spurred by two factors. First, the burst of the Internet bubble in 2000, followed by the demise of Enron, Worldcom and other American and European companies have forced the French administration ${ }^{1}$ to act swiflty in order to improve corporate governance in listed companies. Indeed, a law “on New Economic Regulations” (Nouvelles régulations économiques or NRE) was passed in 2001, and another one on "Financial Safety" (Sécurité financière) was passed in 2003.

Second, the struggle against unemployment has spurred a legal activism in the current right wing French administration in order to give more freedom and more flexibility to small companies. For instance, a law "for Economic Initiative" was passed in 2003 and significantly liberalized the French Société à Responsabilité Limitée (SARL), the French equivalent to the German Gesellschaft mit Beschränkter Haftung (GMBH) and the American Limited Liability Partnership (LLP). ${ }^{2}$ Most recently, Parliament passed in 2005 two laws, one on the "Confidence and modernization of the Economy", 3 and another "to promote small and medium size businesses". ${ }^{4}$

The June 24, 2004 Ordinance $^{5}$ takes place in this situation of legal activism. Therefore, the purpose of the Ordinance was not just to create a new regime of preferred shares. It was more general: simplify and unify the regimes applicable to securities issuance, the procedures for increasing share capital,

1 In France, most laws passed in Parliament originate from the Government.

$2 \mathrm{Law} \mathrm{n}^{\circ}$ 2003-721 of August 1, 2003 pour l'initiative économique, J. O n 179, 5 August 2003 p. 13449.

3 Law n ${ }^{\circ}$ 2005-842 of July 26, 2005 pour la confiance et la modernisation de l'économie, J.O n ${ }^{\circ} 173$, July 27 2005, p. 12160.

4 Law n ${ }^{\circ}$ 2005-882 of August 2, 2005 "en faveur des petites et moyennes entreprises", J.O $\mathrm{n}^{\circ} 179$, August 3, 2005, p. 12639.

5 Ordinance $\mathrm{n}^{\circ}$ 2004-604 of June 24, 2004. JO June 26, 2004. Ordinance taken in application of Article 26 of law n ${ }^{\circ} 2003-591$ of July 2, 2003, which allows the government to simplify the law. Entered into force on June 27, 2004.

An ordinance has the same legal value as a law passed in Parliament, but is adopted by the Excutive branch (Art. 38 of the Octobre 4, 1958 French Constitution). The Ordinance becomes law when a ratification project is presented in Parliament. 
the transfer of securities and other related subjects impacting both listed and unlisted companies. However, the preferred shares is one of the most important parts of the reform.

The creation of the preferred shares also illustrates the trend toward liberalization and Americanization of French corporate law.

First, the new preferred shares rely more on contractual freedom than the previous system. Before 2004, there was a general regime for the action de priorité (priority share), and two specifically tailored regime of the action de préférence sans droit de vote (non-voting preferred stock), created in 1978, ${ }^{6}$ and the certificat d'investissement (investment certificate) and the voting certificate (certificat de droit de vote), created in $1983 .^{7}$

The former had been created to allow the issuance of a limited number of shares, at most $25 \%$ of the stated capital, with no voting rights as long as an increased dividend was paid. ${ }^{8}$ This specific regime was necessary in order to issue non-voting shares since common and priority shares could not be deprived of their voting right. ${ }^{9}$ The idea was to help French companies to increase their capital without their majority shareholders losing control. The investment certificate and the voting certificate had been established for the same reason and with the same limitation on the number of certificates, but were tailored for State owned companies who were badly in need of funds in the early 1980s, although they were not limited to these companies. The deprivation of the voting right for the holders of the investment certificate was permanent. Therefore, as long as the State kept the voting certificates, investors could never have a vote in State owned companies.

Therefore, a general regime lived side by side with two specific very detailed statutory regimes. The ordinance establishes only one general regime, with a few rules and leaves the rest to contractual freedom.

Indeed, the ordinance offers more freedom compared to the older system. For instance, prefered shares can be deprived of voting rights whereas such deprivation was prohibited under the former general regime of the action de priorité. The Ordinance also leaves more freedom to the companies to set up the terms they desire than the previous specific regimes of the action de préférence sans droit de vote and the certificat d'investissement.

6 Law n $^{\circ} 78-741$ of July 13, 1978, modified by law $n^{\circ} 83-1$ of January 3, 1983. Commercial Code former Art. L. 228-11 to L. 228-20.

7 Commercial Code former Art. L. 228-30 to L. 228-35 (Law n ${ }^{\circ} 83-1$ of 3, 1983).

8 The voting right was automatically reestablished when the priority dividend had not been paid during three years. Commercial Code former Art. L. 228-14.

9 Civil Code, Art. 1844. 
This trend toward more contractual freedom in the area of corporate law is not limited to shares. For instance, the 2001 NRE law allowed the Société anonyme to split the offices of chairman of the board and chief executive officer (CEO), which had been merged since $1940 .{ }^{10}$ Also, the 2003 Law on Economic Iniative has reduced the minimum capital requirement for the Société à Responsabilité Limitée from 7500 euros to 2 eurocents. ${ }^{11}$ More recently, the law on the "Confidence and modernization of the Economy" reduced the minimum quorum for extraordinary and ordinary general shareholders, meeting in the Société anonyme but allowed the articles of incorporation to raise it if the company is not public. ${ }^{12}$

The new regime of the preferred shares also reflects the continuing and growing influence of American law and concepts into French law, both in form and substance. For instance, the name of action de préférence itself is designed to refer to the American preferred shares. The Official report accompanying the Ordinance, explicitely states that "These securities are called actions de préférence, translation of an internationally recognized financial practice". ${ }^{13}$ This unnamed internationally recognized financial practice implicitly refers to American law. ${ }^{14}$ The willingness to copy the U.S. model is obvious. Indeed, as Professor Alain Viandier noticed, the term of specific shares would have been more appropriate than preferred shares since a French preferred share can include no advantage at all. ${ }^{15}$

According to Mrs. Elisabeth Grimaud, the increase in contractual freedom reflects an Anglo-American influence as in the U.S. and in the United Kingdom corporate statutory laws give a lot of freedom to the articles of incor-

10 C. com. Art. L. 225-51-1, introduced by Art. 106 of Law n 2001-420 of May 15, 2001 relative aux nouvelles régulations économiques, J. O. $\mathrm{n}^{\circ} 113$, May 16 2001, p. 7776; see M. Storck “Corporate Governance à la française - Current Trends”, ECFR (2004) 36 et seq.

$11 \mathrm{Law} \mathrm{n}^{\circ}$ 2003-721 of August 1st 2003 pour l'initiative économique, J. O n 179, August 5, 2003 p. 13449. On the general debate on legal capital see M. Miola in this issue.

12 Art. 6 (Commercial Code, Art. L. 225-96 and Commercial Code, Art. L. 225-98).

13 Ministry of Justice, Official Report to the President of the Republic, p. 8.

14 The same restraint can be seen in the area of securities law where the prospectus directive allows the use of "a language customary in the sphere of international finance" in a prospectus, which designates English. Article 21 Directive of November 4, 2003 of the European Parliament of the European Parliament and of the Council on the prospectus to be published when securities are offered to the public or admitted to trading and amending Directive 2001/34/EC.

15 A. Viandier, “Les actions de préférence”, JCP ed. E, n 40, 30 September 2004. n 8 to 10 . 
poration compared to French corporate law. ${ }^{16}$ Whether this hypothesis is true is open to debate since French corporate law, especially the 1867 Company Act, was also very liberal in the $19^{\text {th }}$ century.

The reason for this American influence in France is twofold. First, there is a prestige of the American corporate law model. This situation where the law of a country benefits from an influence on others is actually not a new phenomenom. It can be observed as soon as the $17^{\text {th }}$ century with the success of the Dutch East India Company, the first listed company. Its articles of incorporation where copied accross Europe by countries establishing their own competing companies. ${ }^{17}$

The second reason for this influence is that American investors tend to have a strong influence in French listed companies. Moreover, French companies are exposed to strong international competition in order to attract capital. Therefore, France had to offer an instrument close to the international standards and an Americanized labialization can only help marking to U.S. investors.

Actually, many French recent reforms had an American influence. For instance, the $2001 \mathrm{NRE}$ law imposed the individual transparency of executive indemnification, which has long been in effect in the U.S. but was rejected in continental Europe. The 2003 Financial Safety law was also influenced by the 2002 Sarbanes-Oxley Act. ${ }^{18}$ For instance, its internal control provisions are a softer version of Section 404 of Sarbanes-Oxley.

The situation before the 2004 Ordinance, with a general regime prohibiting the deprivation of voting rights, existed alongside two specific regimes designed to allow for a conditional or permanent deprivation of the voting rights was not satisfactory. The general priority shares regime was seldom used due to legal constraints and a lack of certainty regarding the applicable rules. Indeed, only one article of the Commercial Code dealt with priority shares. Companies and practictioners were reluctant to issue priority shares for fear of violating any general rule which application to priority shares could not have been anticipated. As Philippe Bissava put it, "In practice, it was of relatively little use, may be, and paradoxically, because its regime was not

16 Elisabeth Grimaud, “L’influence du droit anglo-américain sur les valeurs mobilières émises par les sociétés anonymes en droit français”, Bibliothèque de droit de l'entreprise, $n^{\circ}$ 67, Litec, 2004. Cf. further on this trend in Europe H. Fleischer, "Legal Transplants in European Company Law - The Case of Fiduciary Duties”, ECFR (2005) 378.

17 Voc 1602-2002: 400 Years of Company Law, by Ella Gepken-Jager, Prof. Gerard van Solinge, Prof. Levinus Timmerman, Aspen Publishers, pp. 459.

18 P.-H. Conac, "L'influence de la loi Sarbanes-Oxley sur la loi de Sécurité financière", Revue des sociétés n 2003-04, p. 835. 
sufficiently defined by the law and because practicioners hesitate to use an area of freedom when this one is too wide, because the custom in corporate law is so much to be constrained by detailed rules". ${ }^{19}$

Therefore, companies were incitated to benefit from the safety of non-voting priority shares or investment certificates, as their legal regime was much more detailed. However, these specific regimes were seldom used due to complex and cumbersome rules. For instance, the increased dividend to be paid to holders of non-voting priority shares was established according to a legal formula that could not be modified.

The creation of the Société par actions simplifiée in 1994, a simplified form of Société anonyme, provided more freedom, as any kind of priority shares, possibly with multiple voting rights, could be issued. However, such a company could not go public and was therefore not useful for public companies or for non-public companies wishing to go public at some point. The 2004 Ordinance is not a major reform with regards to the SAS. Therefore, the following developments will mainly deal with the joint-stock company.

The creation of a new single regime of preferred shares is therefore primarily designed to give venture capitalists a specifice tool in order to finance the companies that will go public. So far, there had been a lack of a legal instrument to meet the conditions of a typical round of venture capital financing. Indeed, venture capitalists desire to have preferred shares rather than common shares, in order to be better protected than insiders (founders and employees) in case of insolvency.

- The creation of the preferred shares by the 2004 Ordinance results from a bottom-up approach. Indeed, the new regime relies heavily on several reports drafted by different French professional organizations advocating for preferred shares and making detailed proposals. One report was drafted in 2001 by the MEDEF, the most important French business organization. ${ }^{20}$ The contents of the 2004 Ordinance have been heavily influenced by this report. A more general report was issued in 2003, by the MEDEF and two other important professional organisations, gathering all their proposal for corporate law reforms. ${ }^{21}$ Finally, a report from the French venture capital

$19 \mathrm{Ph}$. Bissara, "Présentation générale de l’ordonnance portant réforme du régime des valeurs mobilières émises par les sociétés par actions”, Revue des Sociétés, n 2004-03, $\mathrm{n}^{\circ} 9$, p. 466.

20 "Les actions de préférence: propositions du MEDEF pour une modernisation du droit des valeurs mobilières", MEDEF, June 2001.

21 AFEP-ANSA-MEDEF, Pour un droit moderne des sociétés, October 2003. 
association was also used.22 Therefore, the 2004 Ordinance directly results from the request of companies and professionals.

The highly technical dimension of the reform and the consensus surrounding it explain that it was not subject to Parliament, but drafted by the Ministry of Justice. However, this expedited process presents an important drawback. It lacks transparency, although many professional organisations and law firms were consulted on the different drafts. Therefore, in order to interpret the new regime, one has to refer to the short official report accompanying the 2004 Ordinance, who can be considered as the equivalent of a legislative history, and to the previous reports, specially the 2001 MEDEF one report.

One could at least have expected from the use of a non-Parliamentary process a technically perfect reform. Unfortunately, many provisions have proved difficult to understand. The implementing decree was just recently published in February 2005 so that preferred shares could not be issued before this date. $^{23}$

Despite the technical imperfections of the 2004 Ordinance, this reform is highly positive. The new Article 228-11 al. 1 of the Commercial Code allows the issue of preferred shares by stating that "On the formation of the company or during its existence, preference shares may be created, with or without vot-ing rights, granted with specific rights (droits particuliers) of any kind, on a temporary or permanent basis. These rights are set forth in the articles of incorporation, subject to the provisions of Article L. 225-10 and L. 225-122 to L. 225-125”.

The following nine articles provide no restrictions but rather detail the regime of certain types of operations in order to provide the best legal certainty as possible. There are more statutory provision than with the former priority shares, and no stringent restrictions.

However, when no special rule applies, standard statutory provisions governing common shares apply as default rules to all types of preferred shares issued. ${ }^{24}$ Preferred shares are therefore subject to the general principles governing common shares. Those principles include, among others, the respect of the social interest of the issuing company, ${ }^{25}$ the prohibition on fictitious

22 AFIC, Report on the "actions de préférence", commission Venture, July 2003.

23 Decree n $^{\circ}$ 2005-112 of February 10, 2005, JO February 12, 2005, p. 2404.

24 Ministry of Justice, Official Report to the President of the Republic, p. 8.

25 Civil Code, Art. 1833 C. civ., and Commercial Code, Art. L. 242-6. 
dividends ${ }^{26}$ the prohibition of fixed interest provision, ${ }^{27}$ the prohibition of over-reaching clauses (clauses léonines), ${ }^{28}$ the prohibition from suppressing the pro rata preemptive right (droit préférentiel de souscription), and the prohibition on converting shares into debt (upstream conversion). ${ }^{29}$

Apart from these points, the nature of the preferences that can be inserted into the preferred shares is very much open to contractual freedom (see II below). The regime of the preferred shares itself is more regulated (see III below).

\section{The nature of the preference}

Preferred shares can be of an ordinary type (1.) or include special features that are more unusual (2.).

\section{Ordinary preferred shares}

The specific rights (droits particuliers) that preferred shares can enjoy have to be set forth in the articles of incorporation (statuts). ${ }^{30}$ This provision makes sure that shareholders vote on the specific rights that will be granted. The solution is the same with the American Model Business Corporation Act (MBCA). ${ }^{31}$

The preference can be financial or non-financial, mainly political. It can be permanent or temporary.

\section{a) Financial preferences}

The financial preference can consist, inter alia, of an increased dividend, a priority dividend, or a cumulative dividend. Those kinds of preferences concern mainly listed companies as very few start-ups pay dividends. The formula for calculating the dividend is left to the company to decide. The formula can include a cap in order for the priority dividend not to exceed a multiple of the ordinary dividend.

26 Commercial Code, Art. L. 232-12.

27 Commercial Code, Art. L 232-15, al. 1.

28 Civil Code, Art. 1844-1.

29 Commercial Code, Art. L. 228-91.

30 Commercial Code, Art. L. 228-1.

31 MBCA, Section 6.01a. 
The Commercial Code also explicitly provides that the dividend can be paid in shares. ${ }^{32}$ Such a possibility is already explicitly admitted by the French Commercial Code. ${ }^{33}$ However, this provision was inserted because such a possibility had been challenged for investment certificates and it seemed safer to eliminate any new challenge. ${ }^{34}$ However, this duplication raises new issues. ${ }^{35}$

The financial preference can also consist of a preferential right to the proceeds in case of a sale, liquidation or a merger of the company. Such provision is current with venture capitalists as statistically many start-ups run into trouble and are sold before being able to go public. This provision gives a needed protection to outside investors. Typically, the liquidation preference is a multiple of the amount initially paid for the stock, usually two or three times the amount invested.

The financial preference, when holders of preferred shares are venture capitalists, will often consist of a convertibility of the shares into ordinary shares. The Commercial Code allows the terms of the convertability to be freely set up in the articles of incorporation. Usually, conversion will take place when the company goes public because at this stage venture capitalists will sell their shares.

Finally, the financial preference will also often consist of a protection against the issuance of other preferred or ordinary shares. If the company issues multiple rounds of preferred shares, the first investors will want to keep their liquidation preference over the others or at least to be treated equally (pari passu). This provision is very important as start-ups often face difficulties and come in need of new money.

If the company issues later ordinary shares rather than preferred shares, the formula used to convert the convertible preferred stock into shares of common stock usually includes an anti-dilution provision. The justification for this ratchet mechanism is that the first investor might have a difficulty to evaluate the correct value of the start-up. The venture capitalist's valuation is an educated guess. Therefore, in case of over-optimism, indicated by the issuance of new stocks at a cheaper price than the one paid by the first investor, the ratchet mechanism allows the venture capitalist to receive additional stock to make up for the price difference. Before the 2004 Ordinance, such protection could only be gained indirectly through the use of stock warrants

32 Commercial Code, Art. L. 228-18.

33 Commercial Code, Art. L. 232-18 al. 3.

34 Viandier (n 15) $n^{\circ} 59$.

35 Viandier (n 15) n ${ }^{\circ} 59$. 
(bons de souscription d'actions) that could be exerciced in case of issuance of new stock at a lower price.

Under the new provisions of the Commercial Code, all these protections can be inserted into the preferred shares. The only main limitation on financial privileges is the prohibition of the fixed interest provision (clause d'intérêt fixe $)^{36}$ and over-reaching clause. The preferred shares cannot be protected from all losses and cannot receive all dividends whereas ordinary shares would lose all rights to dividends.

\section{b) Political preferences (or non-financial privileges)}

Preferred shares can also provide for non-financial or political privileges. These privilege can concern the voting power but can also consist of other privileges.

Privileges not relevant to the voting power are shorter to list. They can mainly consist of increased information than is usually applicable to ordinary shareholders. This privilege is highly interesting in start-ups. However, in listed companies, it seems dangerous, as investors could be deemed insiders and prohibited from trading.

The voting right can be suppressed, suspended, kept, increased or adapted to the specific needs of the investors.

First, the voting right of the preferred shares can be suppressed. This is the main innovation of the 2004 Ordinance since before only specifically tailored shares could be deprived of their voting rights. The principle was so powerful, in the case of priority shares without voting rights, that the suppression of the voting right was merely a suspension. In case that the increased dividend was not paid during three years, the holders of those shares would recover their voting rights.

The suppression of the voting rights will usually concern listed companies rather than start-ups. Indeed, in start-ups, venture capitalists need to keep some control of the management. However in listed companies, minority shareholders can easily accept losing their voting rights in exchange for an increased dividend.

The voting right can also be kept with no specific adaptation. In such case, a preferred share is close to a common share. 
The voting rights can also be temporary suspended. For instance, preferred shareholders will usually regain the right to vote in the event the corporation fails to pay dividends over four or six quarterly periods.

The preferred shares can also provide increased voting rights. However, they cannot provide multiple voting rights. French law is very restrictive with multiple voting rights, with the exception, since 1994, of the Société par actions simplifiée. A 1903 law had authorized joint stock companies to issue priority shares with the same voting rights as common shares "except contrary provisions of the articles of incorporation". ${ }^{37}$ It was therefore possible to issue priority shares with multiple voting rights. Thoses shares would keep this advantage even when sold. However, as noted by Professor Yves Guyon, "Shortly after the first World War, these shares were issued in order to fend off attemps to take control which had been made easier by the collapse of the stock market". ${ }^{38}$ The practice soon turned abusive. Therefore, Parliament prohibited the issuance of such shares for the future in 1930, ${ }^{39}$ and prohibited them altogether in $1933 . .^{\circ}$ An attempt, when the 1966 Law on commercial companies was introduced, to reintroduce shares with multiple voting rights failed. ${ }^{41}$

The 2004 Ordinance keeps this prohibition. This is why there is a reference in Article L. 228-11 to the fact that "These rights are set forth in the articles of incorporation, subject to the provisions of Article L. 225-10 and L. 225-122 to L. 225-125". Article L. 225-122 states that the voting rights attached to "shares shall be in proportion to the share of the capital they represent and each share shall entitle the holder to at least one vote". In order to issue shares with multiple voting rights, one has therefore to establish a Société par actions simplifiées, as Article L. 225-122 is not applicable and the freedom to tailor shares is more extensive. This is a major difference with the United States. ${ }^{42}$

The only advantage in terms of multiple voting rights that preferred shares can give, is that French and European Union investors who have held their

37 Art. 34 of the 1807 French Commercial Code. Law of November 16, 1903.

38 Y. Guyon, Traité des contrats, Les sociétés: aménagements statutaires et conventions

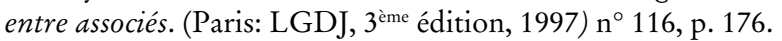

39 Art. 6 of the Appropriation Law of April 26, 1930.

40 Law of November 13, 1933.

41 Hémard, Terré et Mabillat, Sociétés commerciales (Dalloz, t. II, 1978) nº 195.

$42 \mathrm{MBCA}$, Art. 6.01c allows shares with multiple voting rights. 
shares for at least two years can be given a double voting right. ${ }^{43}$ This provision dates back to 1933 and was designed to compensate for the prohibition of multiple voting rights. This system is widely used in most major French listed companies as an anti-takeover device. However, such shares are not real shares with multiple voting rights since the privilege is not attached to the share but to the holder. Therefore in case of resale of the stock, the double vote is lost. Also, in case of a takeover, Article 11 of the April 21, 2004 takeover directive that suspends multiple voting rights when voting on anti-takeover defences is not applicable.

Finally, the voting rights of the preferred shares can be specifically tailored. It is possible to design a selective voting right that will come into play only for certain shareholders' meetings (ordinary or extraordinary) or for certain decisions, that will be proportionnate to a certain decision but reduced on others, that could be only exerciced only after a certain period etc. ...

Usually in start-ups, the voting rights conferred on the preferred stock often include the right to elect one or more directors to the company's board of directors. The 2004 Ordinance allows for such possibility. Case law also allowed for such a possibility as long as shareholders have the choice between at least two different candidates.

Preferred shareholders also often want to approve certain major decisions. Common major decisions include the issuance of additional shares of stock to others, the sale or merger of the business, the creation of new stock with preferential rights and the change of the company's core business activity. The issue is whether preferred shareholders can have a veto right on such decisions. The answer is subject to debate and various positions have been expressed. A veto right in the general shareholders' meeting is not possible. ${ }^{44}$ The reason is twofold. First, majority rules cannot be modified, and a veto right given to preferred shareholders would be an implicit modification. Second, according to article L. 225-122 of the Commercial Code, the voting right of the preferred shares has to be proportionate. Allowing a veto right would run afoul of this principle.

A veto right on the board of directors is also prohibited, although the Commercial Code allows the majority to be modified ${ }^{45}$ and the issue is more open to debate. The reason for such prohibition is that the board is a collegial body

43 Commercial Code, Art. L. 225-123.

44 A. Guengant, D. Davodet, Ph. Engel, S. de Vendeuil, S. Le Pavec, idem, p. 1162.

45 Commercial Code, Art. L. 225-37. 
and a veto right given to the representative of preferred shareholders would eliminate this collegiality.

Finally, such a right could contradict the legal repartition of powers among shareholders and management in the Société anonyme. ${ }^{46}$ Indeed, a landmark 1946 decision from the Cour de cassation, the French highest judicial court established as a principle that shareholders and management could not deprive one another of their legal duties. ${ }^{47}$ Therefore, there is always a risk when modifying the legal organization of powers within the Société anonyme to run into the prohibition established by the 1946 Motte decision.

An indirect way to give some form of control to the representatives of the preferred shareholders in the board of directors would be to increase the majority so that the representative votes would be necessary to make a decision. This reinforced majority could concern only certain types of decisions sensitive to preferred shareholders such as, for instance, a sale of assets.

\section{Specific preferred shares}

Preferred shares can be specific in two ways. First, in spite of their name, they might provide no advantage at all for their holders. Second, they might be used within a group.

\section{a) Possibility of a lack of advantage}

In the 1978 legal regime of the priority shares without voting rights, the Parliament had balanced the suppression of the voting rights with an increased, priority and cumulative dividend. ${ }^{48}$ The situation is much less favorable to holders with the new preference shares.

It is true that article L. 228-11 of the Commercial Code states that "preference shares may be created, with or without voting rights, granted with specific rights (droits particuliers) of any kind, on a temporary or permanent basis.". The use of the term "specific rights" could be plainly interpreted as meaning "advantage". However, it is not the majority interpretation of this

46 M. Germain, “Les actions de préférence”, Revue des Sociétés, n²004-03, n 8, p. 600.

47 Cass. Civ., 4 juin 1946 Motte, JCP 1947, II, 3518, note Bastian; J. Noirel, in Les grands arrêts de la jurisprudence commerciale (Sirey, 1962) p. 235.

48 Commercial Code, former Art. L. 228-13. 
text by most legal scholars. The term "rights" is explained in the official report accompanying the 2004 Ordinance as having a generic meaning and simply refering to a different legal status than common shares. As Professor Alain Viandier puts it, it is the "alterity and not the privilege which characterizes the preference share" ${ }^{49}$ This interpretation is supported by the fact that in the former Article L. 228-11 of the Commercial Code, the text explicitly used the term "advantage". Besides, preference shares also replace investment certificates which granted no specific advantage. The term preference share is therefore misleading since no advantage could be granted. The term "difference share" would better characterize the situation.

Preference shares can also be different from common shares by the fact that they support specific obligations or have reduced rights. For instance, a specific obligation could be an inalienability clause, which is legal under French law if certain conditions are respected. It seems very theoretical that investors would agree to buy preference shares with both no voting rights and a reduced dividend. However, this would be legal.

\section{b) Nature of the preference within a corporate group (art. L. 228-13 c. com.)}

The most significant innovation of the 2004 Ordinance certainly concerns preference shares within a group. Under French law, there is no organized system of rules governing corporate groups, but a handful of provisions, dealing for instance with financial information or consolidated financial accounts. ${ }^{50}$ There is also some case law especially in the area of corporate abuse. $^{51}$

Article L. 228-13 of the Commercial Code provides that the "specific rights" can be exercised in the parent company, being defined as having directly or indirectly more than $50 \%$ of the outstanding capital of the issuer, or in the subsidiary, being defined as having more than $50 \%$ of the outstanding capital being controlled directly or indirectly by the parent. In summary, shareholders can exercice their special rights against their direct or indirect parent company or their direct or indirect subsidiaries. So far, a previous provision only allowed the issuance of rights by the subsidiary, giving rights to shares

49 Viandier (n 15) n 10 p. 1529.

50 Commercial Code, Art. L. 225-100.

51 M.-E. Boursier, "Le fait justificatif de groupe de sociétés dans l'abus de biens sociaux: entre efficacité et clandestinité. Analyse de vingt ans de jurisprudence criminelle.”, Revue des sociétés, $\mathrm{n}^{\circ}$ 2005-02 p. 273. 
of the parent company. This provision was very limited in scope. Tracking stocks could also be issued, using the priority shares regime, but they could only give rights to the economic substance of the subsidiaries and not a legal access to the subsidiaries.

The issuance of those shares must be authorized by an extraordinary shareholders' meeting of the issuer and of the company with respect to which the rights attached to the preferred shares will be exercised. A majority of French academics consider that those rights cannot be a right to the dividend or a voting right. According to this analysis, it could not be a right to the dividend paid by the parent company or the subsidiary because the preferred shareholder is not a direct shareholder of the paying company. ${ }^{52}$ In order to receive a dividend, one has to be a shareholder of the paying company. The "specific right" in the parent company or the subsidiary cannot be a voting right. The main reason is that in order to vote, one has to be a direct shareholder. ${ }^{53} \mathrm{Be}-$ sides, according to Professor Michel Germain, the "specific rights" could not be voting rights. ${ }^{54}$ Finally, the proportionality principle, establihed by Article L. 225-122, also applies here. ${ }^{55}$

This majority interpretation does not leave room for a wide range of specific advantages. The specific right could mainly be an increased access to information, ${ }^{56}$ or a right to be consulted. ${ }^{57}$ Such restrictive interpretation is not certain. First, to say that the "specific rights" exclude the voting rights is not certain. If voting rights were really excluded, the second sentence of Article L. 228-11 would not provide that those specific "rights" have to comply with several rules related to voting rights. Second, it could be considered that holders of prefered shares are shareholders of the group, which is a general entity to be considered globally. Finally, it could be considered that Article L. 228-13 has implicitly set aside Article L. 225-122 of the Commercial Code relating to the proportionate rule in the area of voting rights.

52 Viandier (n 15) $n^{\circ} 41$.

53 Ansa, n 04-080, Actions de préférence: exercice des droits particuliers dans une société contrôlée ou contrôlante, December 1, 2004.

54 Germain (n 46) 601.

55 Y. Paclot, Les actions de préférence: jusqu'où ne pas aller trop loin?, N3589ABK, LEXBASE HEBDO $n^{\circ} 144$ du Jeudi 25 Novembre 2004 - Edition AFFAIRES.

56 Germain (n 46) n 10 , p. 601; Y. Paclot, idem.

57 Viandier (n 15) $n^{\circ} 46$. 


\section{The regime of the preferred shares}

The Commercial Code provides for the creation and suppression of preferred shares, but also provides protections to preferred shareholders.

\section{Creation and suppression preferred shares}

\section{a) Creation of preferred shares}

\section{aa) Issuance of preferred shares through capital increace}

The issuance of preferred shares has been eased compared to the former priority shares without voting rights. These previous shares could only be issued if the company had had positive earnings during two years. Their issuance has also been eased compared to priority shares. Preferred shares can be issued even if securities giving right to equity have been issued, ${ }^{58}$ whereas it was not possible before the 2004 Ordinance.

The competent body for deciding whether to issue preferred shares is the extraordinary shareholders' meeting. This is not a surprise, as this assembly is competent on all issues regarding capital, and was therefore already competent to issue priority shares or investment certificates. The extraordinary shareholders' meeting mainly differs from the ordinary meeting by the increased quorum and majority required to pass a vote. The shareholders can delegate their power to issue preferred shares to the board of directors or to the executive board (directoire, in German Vorstand), the same way as for common shares. ${ }^{59}$ However, for preferred shares, a special resolution is required in order to draw the attention of the shareholders. ${ }^{60}$ Besides, the specific rights cannot be defined by the board of directors or the executive board alone, as they have to be set forth in the articles of incorporation. This serves as a protection for shareholders.

The shareholders vote on the issuance of the preferred shares after receiving a special report from the board of directors which states the characteristics of the preferred shares and the impact of the issuance on the situation of holders of equity securities and securities giving right to equity secu-

58 Commercial Code, Art. L 228-98, al. 3.

59 Commercial Code, Art. L. 225-129-2.

60 Commercial Code, Art. L 225-129-2, al. 3. 
rities. ${ }^{61}$ The statutory auditor (commissaire aux comptes) gives his "opinion" on all the points included in the report of the board of directors. ${ }^{62}$

When the preferred shares are offered to one or a group of nominatively identified current or future shareholders, the 2004 Ordinance provides that the company has to apply the procedure in the event of the specification of special benefits (procédure des avantages particuliers). ${ }^{63}$ This procedure aims to manage conflicts of interests and was already applicable in the case of the former priority shares when the preferences were linked to the individual as opposed to included in the shares. Therefore, the beneficiaries of the preferred shares cannot vote on the issuance neither for themselves nor as agents. ${ }^{64}$

An independant statutory auditor, who cannot be the current or former (five years at least) statutory auditor of the company will have to be appointed ${ }^{65}$ by the president of the competent first degree commercial court (tribunal de commerce) ${ }^{66}$ Regulations prescribe in great detail the content of the report ${ }^{67}$ which must, among others, state the value of the benefits attached to the preferred shares.

When the preferred shares have no voting rights, a special rule applies to their issuance. Non-voting preferred shares may not represent more than $50 \%$ of the capital stock or more than $25 \%$ of the capital stock of companies, the securities of which are listed on a regulated stock exchange. ${ }^{68}$ This provision is essential, as it prohibits the issuance of non-voting preferred shares to the extent that only a handful of voting shareholders could control the company.

The $25 \%$ ceiling was already in place for the former non-voting priority shares ${ }^{69}$ and the former investments certificates. ${ }^{70}$ It has not been increased most probably because listed non-voting shares contradict corporate governance principles. Another reason is probably that French corporate law, con-

61 Decree of March 23, 1967, Art. 206-2.

62 Decree of March 23, 1967, Art. 206-2.

63 Commercial Code, Art. L. 228-15.

64 Commercial Code, Art. L 228-11, al. 1, by reference to Art. L 225-10

65 Commercial Code, Art. L 228-15, al. 1, by reference to Art. L 225-8, L 225-14, and L 225-147.

66 Decree of March 23, 1967, Art. 169, al. 2.

67 Decree of March 23, 1967, Art. 169-3, al. 2.

68 Commercial Code, Art. L. 228-11.

69 Commercial Code, former Art. L. 228-12.

70 Commercial Code, former Art. L. 228-30. 
trary to some some smaller European countries, such as for instance Switzerland, ${ }^{71}$ has been reluctant, at least since 1933 , to legally separate ownership and control. The only exception is to cap voting rights. ${ }^{72}$ However, such a cap is subject to a break-through rule in case of succesful takeover.

In non-listed companies, the non-voting preferred shares can represent up to $50 \%$ of the capital stock, which is a significant increase compared to the previous specific regimes. However, in venture capital, outside investors can easily represent more than half of the shares. But, the drafters of the 2004 Ordinance probably did not want to allow more non-voting shares than $50 \%$ of the capital stock in order not to break the link between ownership and control.

\section{bb) Conversion of ordinary shares or priority shares into preferred shares}

Preferred shares can also be created by conversion from common shares. The Commercial Code does not provide explicitly for that but the official report explicitly states this possibility and one article provides that holders of common shares that are to be converted into preferred shares cannot take part in the vote. ${ }^{73}$ Besides, the previous texts concerning non-voting priority shares allowed for such conversion from common shares, and there is no reason to think that a prohibition took place.

The competent body is also the extraordinary shareholders' meeting. ${ }^{74}$ The holders of the common shares which will be converted into preferred shares cannot vote. Although the law and the regulations are silent on any report submitted to the shareholders, it seems prudent to establish the same reports as in the case of an issuance of new stock.

Previously issued specific regime securities can also be converted into preferred shares.

71 In Switzerland, a company can issue non-voting priority shares called bons de participation (Art. 656a et seq. of the Swiss Code of Obligations) and investment certificates called bons de jouissance (Art. 657 et seq. of the Swiss Code of Obligations). The amount of bons de participation cannot be higher than the double of the amount of shares. There is no such limit on the bons de jouissance.

72 Commercial Code, Art. L. 225-125.

73 Commercial Code, Art. L 228-15, al. 2.

74 Commercial Code, Art. L. 228-12 al. 1. 
cc) Conversion of preferred shares into new preferred shares

New preferred shares can also be created from previous preferred shares. The Commercial Code does not deal explicitly with this type of conversion but it is not prohibited by any principle and a special disposition deals with the conversion resulting from a merger or a split. ${ }^{75}$ Those new preferred shares can be less advantageous, equivalent or more advantageous (upstream conversion) than the previous. An upstream conversion is therefore possible like in the U.S. ${ }^{76}$

\title{
b) Suppression of preferred shares
}

The 2004 Ordinance deals in great detail with the suppression of preferred shares. This is a way to suggest that preferred shares should not be eternal.

\section{aa) Conversion of preferred shares into ordinary shares}

Preferred shares can dissapear by way of conversion into common shares. Such conversion must be decided by the extraordinary shareholders' meeting ${ }^{77}$ and the decision can be delegated, by a special resolution ${ }^{78}$ to the board of directors or the executive committee. ${ }^{79}$ The vote on the conversion is equivalent to a renunciation of other shareholders to their preemption rights (droit préférentiel de souscription). ${ }^{80} \mathrm{~A}$ report by the board of directors must establish, among others, the conditions of the conversion, the techniques used for establishing the conversion rate and the characteristics of the new preferred shares. ${ }^{81}$ The statutory auditor gives his opinion on the conversion and, among others, indicates if the techniques used for establishing the conversion rate are "true and fair". The modalities of the conversion can also be set forth in the articles of incorporation. ${ }^{82}$

Convertible prefered shares should be very common. Convertible preferred stock will often automatically convert to common stock upon certain events. Such events typically occur when the company makes its initial public offer-

\author{
75 Commercial Code, Art. L. 228-17. \\ 76 MBCA, Section 6.01(c). \\ 77 Commercial Code, Art. L. 228-12 al. 1. \\ 78 Commercial Code, Art. L. 225-129-2, al. 3. \\ 79 Commercial Code, Art. L. 228-12 al. 1. \\ 80 Commercial Code, Art. L. 225-132, al. 5. \\ 81 Decree of March 23, 1967, Art. 206-3. \\ 82 Commercial Code, Art. L. 228-12 al. 2.
}


ing or is subject to a takeover. When the extraordinary shareholder' meeting modifies the articles of incorporation, the vote takes place after receiving a report from the board of directors and the opinion of the statutory auditor. ${ }^{83}$ The conversion can also result from an extinction of the advantages at a specific agreed upon date.

In case the conversion entails a reduction in capital stock not associated with losses, creditors may lodge an objection to the reduction ${ }^{84}$ with the first degree commercial court..$^{85}$ The court order can reject the objection or order either the repayment of the debts or the formation of guarantees if the company offers them and if they are judged adequate.

\section{bb) Buy-back or redemption}

The buy-back can be decided by the extraordinary shareholders' meeting, ${ }^{86}$ after receiving a report from the board of directors and the staututory auditors similar to those established in case of conversion. ${ }^{87}$ The buy-back or the redemption must have been set forth in the articles of incorporation, in order to comply with Article 36 of the 1976 second European Directive.

The Commercial Code also provides that the buy-back can be organized $a b$ initio by the articles of incorporation. ${ }^{88}$ The extraordinary shareholders' meeting votes after receiving a report by the board of directors and the statutory auditors. The Commercial Code therefore clearly reestablishes in the case of preferred shares a freedom that had been admitted by case law in the first half of the $20^{\text {th }}$ century even for common shares, ${ }^{89}$ but that had been suppressed by the 1966 Commercial Companies Act. French corporate law is therefore getting closer to American law which allows for redeemable shares. The $\mathrm{MBCA}^{90}$ and New York Corporation Law ${ }^{91}$ also allow for redeemable shares.

83 Decree of March 23, 1967, Art. 206-5.

84 Commercial Code, Art. L. 228-14.

85 Decree of March 23, 1967, Art. 180, by reference from Art. 206.

86 Commercial Code, Art. L. 228-12 al. 1.

87 Decree of March 23, 1967, Art. 206-4.

88 Commercial Code, Art. L. 228-12 al. 2.

89 Paris Court of Appeals, April 3, 1939, SA Au planteur de Caïffa, Journ. Soc 1939, p. 357; Chamber of Request of the Court of Cassation, November 16, 1943, $S A A u$ planteur de Caïfa, JCP 1944, II, 2589, note D. Bastian.

90 MBCA, Section 6.01.

91 NYBCL \512. Redeemable shares. 
The repurchased shares must be nullified. This process is therefore a redemption ${ }^{92}$ and is subject to the opposition right of creditors in case of reduction in capital stock not associated with losses. The redemption can be automatic, at the discretion of the issuer or of the holder, ${ }^{93}$ or dependent of a certain or uncertain event, at a certain time or at any time. If the redemption is decided by the company, it must be imposed upon all holders in order to comply with the equality of shareholders principle. A redemption price formula can be set up in advance, but the price should preferably not be decided in advance, as this might violate the prohibition on overreaching clause. ${ }^{94}$

When the preferred shares are listed on a regulated market, a special provision of the Commercial Codes allows them to be buyable or redeemed at the option of the company or the holders if the market is not liquid, under the conditions set by the articles of incorporation. ${ }^{95}$ The buy-back or the redemption must be decided by the extraordinary shareholders' meeting after receiving the usual report from the board of director and the statutory auditor. ${ }^{96}$ This provision is inspired by a similar regulation in French securities law that provides that in case of lack of liquidity and where the majority shareholder(s) hold $95 \%$ or more of the voting rights of a company whose shares are traded on a regulated market, any holder of voting equity securities who does not belong to the majority group can apply to the Autorite des Marchés Financiers (AMF), the French securities regulator, to require the majority shareholder(s) to file a buyout offer. ${ }^{97}$

Often, the markets of listed non-voting priority shares have proven to be illiquid and the 2004 Ordinance has therefore organized a special provision, where even if there is not a $95 \%$ shareholder whose controling stake explains for the lack of liquidity, the company can eliminate the unsuccessful preferred shares or any a shareholder can regain liquidity from the issuer itself. This liquidity clause should therefore encourage and make it easier for a company to issue listed preferred shares.

It is advisable that the articles of incorporation give a definition of the lack of liquidity and the method for establishing the redemption price. The case law

92 R. Mortier, “Rachat d'actions et actions rachetables”, Rev. Soc. n $32004, n^{\circ} 34$, p. 652.

93 R. Mortier, idem, $\mathrm{n}^{\circ} 28$ et seq, p. 649 et seq.

94 ANSA, n 05-001, Rachat des actions de préférence, January 5, 2005.

95 Commercial Code, Article L. 228-20.

96 Decree of March 23, 1967, Art. 206-5.

97 Article 236-1 of the Financial Markets Authority General Regulation (Règlement général de l'Autorité des marchés financiers). 
developped in the area of securities law could be used althought it concerns situations where the lack of liquidity was more significant.

Listed preferred shares can also be the object of a public purchase offer if the company is subject to a takeover. A 2001 Paris Court of appeals decision protected the priority shareholders by deciding that the same criteria should be used that for the common shares to asses the value of the shares. The initiator had used different criteria in order to lower the price of the non-voting priority shares. This decision should have an influence on the determination of the redemption price by the articles of incorporation.

\section{Protection of holders of preferred shares}

Holders of preferred shares also benefit from a specific protection during the life of their shares either in case of changes in the company or spontaneously.

\section{a) Protection of holders in case of changes in the company}

The Commercial Code provides that the extraordinary shareholders' meeting or the articles of incorporation determine the consequences for the preferred shareholders of changes in, which includes an increase, or amortization, of the issuer's capital. ${ }^{98}$ This provision is aimed at protecting preferred shareholders like creditors or bond holders against modifications of the capital.

The protection of holders mainly takes place trough the preferred shareholders' special meeting. Under French law, every category of shares must be represented by a special meeting, which is entitled to vote on issues concerning those shares. In the U.S., the MBCA provides for a special meeting of priority shareholders. ${ }^{99}$ Delaware Corporation Law also provides for a special meeting, "if the amendment would ... alter or change the powers, preferences, or special rights of the shares of such class so as to affect them adversely". ${ }^{100}$

The special meeting vote is necessary to approve all modifications of the status of the preferred shares, such as a reduction of the preferred dividend. This also includes the decision to convert the preferred shares, to merge with another company or to make a spin off. ${ }^{101}$ However, the Commercial Code provides that if preferred shareholders receive preferred shares granting equi-

98 Commercial Code, Art. L. 228-16.

99 MBCA Section. 6.01(c).

100 Section 242(b)(2) of the Delaware General Corporation Law (DGCL).

101 Commercial Code, Art. L. 236-9 al. 2. 
valent specific rights, no class vote is required. ${ }^{102}$ The Commercial Code gives no definition of the qualifier "equivalent" and it is therefore advisable that the articles of incorporation define this term. For instance, granting additional rights should be considered as "equivalent" since they provide a benefit.

French corporate law appears to be more protective of preferred shareholders than for instance Delaware corporate law. Indeed, under Delaware General Corporation Law Section 251(c), there is no requirement for a class vote in a merger. Such vote will not be granted by the courts. It has to be provided for in the articles of incorporation. ${ }^{103}$ Provisions giving holders of preferred stock a class voting rights in a merger usually require not only the amendment, alteration or repeal of the issuer's charter, but also a material and adverse effect on the preferred stock resulting from such action. The new provision of the French Commercial Code therefore appears to have been inspired by the American practice, but is much more protective of preferred shareholders.

The special meeting decides with the same quorum as does the extraordinary shareholders' meeting. This quorum has just been lowered (by July 26, 2005). From one half on first convocation, one quarter on second convocation and no quorum afterwards to one third on first convocation, one fifth on second convocation and no quorum afterwards. In non public companies, since 2005, the articles of incorporation can set higher quorums.

The special meeting votes after receiving the reports provided to the extraordinary shareholders' meeting. ${ }^{104}$

\section{b) Protection of holders at their request}

The Commercial Code provides that the preferred shareholders' meeting can ask the statutory auditor to prepare a report on the protection of their specific rights. ${ }^{105}$ They do not even need to invocate an irregularity. This report includes the opinion of the statutory auditor on whether the specific rights have been disregarded. This report is to be paid by the company itself, which is why the Commercial Codes explicitly provides for a special report. ${ }^{106}$

It is somewhat surprising that this report must be conducted by the statutory auditor, who is an accounting expert, and not by an expert in the area of

102 Commercial Code, Art. L 228-17.

103 Warner Communications, Inc. v. Chris-Craft Industries, Inc., 583 A2.d 962 (Del. Ch. 1989).

104 Decree of March 23, 1967, Art. 206-6.

105 Commercial Code, Art. L. 228-19.

106 Decree of March 23, 1967, Art. 206-7. 
shareholder protection. The reason might be that the drafters of the 2004 Ordinance considered the statutory auditor, who must prepare the reports dealing with the issuance, conversion, buy-back or redemption of preferred shares, should have a close knowledge of the specific rights attached to them. French law has regularly increased the number of non-auditing mission entrusted to statutory auditors, like most recently a report on corporate governance, may be because their independance has been significantly reinforced by the 2003 Financial Security Act, even above what is expected to be imposed by the future Audit Directive.

\section{Conclusion}

The new regime of the preferred shares is, except in the area of corporate groups, an evolution rather than a revolution in French corporate law. Listed companies could already issue non-voting priority shares, which they had done rather rarely. Non public companies could also already issue also already specific shares with more freedom than the current preferred shares as long as they chose to incorporate as a Société par actions simplifiée.

Therefore, the first real interest of the 2004 reform is to help venture capitalists and ease the smooth transition from non listed companies to listed companies. Indeed, a Société par actions simplifiée cannot go public. It must first transfer itself into a joint-stock company, which can be difficult if priority shares have been issued.

The second real interest of the 2004 reform is that the suppression of the two specific regimes and the creation of a general regime which gives more freedom than before, either by allowing the total suppression of the voting right, or by suppressing unnecessary legal constraints on the issuance of preferred shares. This move is theoretically very important, as usually French Parliament used to create a special regime in order to give more freedom to companies. The creation of non-voting priority shares in 1978, the creation of specific regimes of securities giving access to the capital in 1985, or of the Société par actions simplifiée in 1994 are examples of this usual approach. The drafters of the 2004 Ordinance have given up this approach and chosen to liberalize the main regime itself. This is a major evolution which brings France closer to the U.S.

Therefore, France, as many other countries in Europe, is experiencing not a race to the bottom, ${ }^{107}$ but a walk to the American coporate law model.

107 William Cary, "Federalism and Corporate Law: Reflections upon Delaware”, 83 Yale L. J., 663, 666 (1974). 
However, French corporate law is keeping some specificities and more statutory protection for preference shares than in the U.S. For instance, the Commercial Code keeps a cap on the issuance of preferred shares in non listed companies. France also keeps a rigorous protection of creditors and preferred shareholders in case of reduction of capital whereas the significance of capital itself has almost disappeared.

If past is any guide, some of the remaining rigidities will probably be discarded in the future as the process to become more competitive and the influence of American law will continue to remain unescapable. 